\title{
Islam and cultural changes in modern Africa
}

\begin{abstract}
Islam's first contact with Africa was with Ethiopia rather than Egypt and the rest of North Africa. After the initial military phase in North Africa, Islam spread through the population movements and trade. Another factor that helps the spread of Islam in Africa is its adaptability culture where the customs and usages of a society are accommodated to some extent. The paper argues that Africans before the colonial had established Quranic schools throughout the continent and some of their languages like Hausa and Fulfulde were being written with Arabic alphabets. The paper further states that Islam had been introduced in the Hausa states as early as $14^{\text {th }}$ century, but by the early $19^{\text {th }}$ century it had little influence on the life of most of the inhabitants. The ruling class who would not want to see their power and authority curtailed by the Shariah vigorously opposed the reform of Shehu Uthman and this led to combatant Jihad and subsequent establishment of the Sokoto Caliphate. The system worked vine for a while but the degeneration later set in. The remnant of the degenerated caliphate was what the British had fought with and conquered. The paper concludes that Islam though less widely distributed geographically, but the main political and social forces in the whole continent. Today Islam is probably the fastest growing religion on the African continent, and the proselytization is undertaken by the African Muslims themselves and through peaceful means. Their Jihad is not terrorism; terrorism is under no circumstances permissible in Islam.
\end{abstract}

Keywords: adaptability, arabization, culture, islamaization, proselytization, religion
Volume 2 Issue I - 2018

\author{
Abdulmajeed Hassan Bello \\ Department of Religion and Cultural studies, University of UYO, \\ Nigeria
}

Correspondence: Abdulmajeed Hassan Bello, Department of Religion and Cultural studies, University of UYO, Nigeria,Tel +2348022I21928, +2348037199987.

Email abdulmajeedhassan@uniuyo.edu.ng, abdumajeedbello@gmail.com

Received: November 17, 2017 | Published:January 22, 2018

\section{Introduction}

Islam is the world's fastest growing religion and at its present rate of expansion it will soon be the predominant religion of mankind. This is not a new or unexpected statistic, however it is something that is slowly making people re-examine their understanding of a religion of which many remain ignorant. Some are taking positive step, and by educating themselves they are discovering the truth of what Islam has to offer. Unfortunately, even in the developed world, this is not as easy as one might hope. Although there has been great progress in the dissemination of information, the information that is made available is not always that helpful or as unpolluted as one is led to believe.

Today, Islam is one of the main political and social forces in many parts of the African continent, south as well as North of Sahara. The Muslims population in black Africa proper is more widely distributed and uneven, but with the exception of Sudan, no state in this region regards itself as Islamic in the sense in which states in North Africa do; black Africa may be regarded as a major Islamic world theatre ${ }^{1}$.

How did Islam attain such an important in this vast area? In addition, what special characteristics has Islam acquired in Africa? This is partly an attempt to understand the interaction between Islam and the Africans of particular interest, here is the Question of whether or not Islam success in Africa was due to forced conversions. Thus our proper understanding of Islam and its role in uplifting the African people would be of a great benefit for the whole continent. Thus the paper focuses on Islamization and Arabization of the North Africa, Islam in the rest of African continent, Adaptability culture of Islam, the role of trade in the Islamaization of Africa, Islamic education in Africa, Islamic culture and Shariah in Nigeria and conclusion.

'Kokole, Omari H. Religion in Afro-Arab Relations. In: Nura Alkali, editor. Islam in Africa. Nigeria: spectrum Books Limited; 1993. 232 p.

\section{Methodology and theoretical framework}

The basic research methodology for this paper is historical and descriptive. As religion plays an important role in Nigeria, it is essential to examine Islam's facets in general and how that links to peace theories. 'Islam" literally means peace, surrender of one's will; and to be in amity Islam is the attainment of a life of perfect and eternal happiness through completed surrender to the will God. Islam is the last of the great religions. It embraces all religion, which was before it, and one of its most striking characteristics is that it requires its followers to belief in the entire prophet who preceded Prophet Muhammad. Islam is monotheistic religion. God has no associates or equals is the fundamental principle of Islam. ${ }^{2}$ Islam is a complete code of life, providing instructions for its followers in all aspect of life- the kind of food that they may be eaten, the way one should dress, how one should conduct business, social graces, marriage divorce and human rights. The Holy Book of Islam- Qur'an provides a standard therefore by which one may live one's life. However, Islam throughout, instructed to reason and Question and reflects upon what it written. Above all, it is stressed that there is no compulsion in religion. Belief cannot enforce upon people; indeed, if it were it would be meaningless. The presence of Islam is not force, but persuasion. ${ }^{3}$

"Culture" is the customs, beliefs, art, music and all the other products of human thought made by a particular group of people at a particular time. ${ }^{4}$ This definition implies that; the culture of a people or community comprises how they live, what they believe, what they cherish (arts), their social values, political system, what they eat, wear and so on. ${ }^{5}$

${ }^{2}$ Saqi, Sarah. An introduction to Islam. The Review of religions. 1986;2:14-18. ${ }^{3}$ Saqi. p. 16.

${ }^{4}$ Quirk, Randolph. Dictionary of Contemporary English. Essex: Longman Group UK Limited; 1987. 251 p.

${ }^{5}$ Shoboyede TO. Religion and culture. The Truth. 1992;2:3-6. 
"Africa" African continent is the second largest continent in the world, with the Mediterranean Sea to the north, the Atlantic Ocean to the west and Indian Ocean to the east. ${ }^{6}$ The truth is that, apart from African union (AU), in nearly all international organizations, the Arab countries of Africa, from Mauritania to Egypt, the Sudan, Eritrea and Somalia, identify with the Arab. Africa thus tends to mean south of the Sahara or non-Arab Africa. The Sahara desert, unfortunately, tends to be looked down upon, not as a formidable landmark, which unites Africa, but as a misfortune, which divides Africa. This may be practical; but it does not make the treatment of the definition of Africa easy and has other complications. Africa is here treated as one, ignoring the Sahara desert, while making distinctions whenever necessary. ${ }^{7}$

It's hard to claim that South Sudanese culture is Arab or African in a globalized world where it's very difficult to claim cultural uniqueness as a group, let alone a group such as South Sudan which blended with the North for more than a decade. Deng Aling weighs in on this contentious identity discussion. Speaking about culture leads us right into speaking about identity. The identity discussions were hashed out over decades in cultural and academic spheres in Sudan before the secession of the South to form the Republic of South Sudan. The discussions have a historical backdrop, deeply rooted in the minds of many Sudanese about the identity of Sudanese culture; if it is Arab or African. ${ }^{8}$

Although it may be difficult to validate each of the two claims, many Northern and Southern Sudanese writers and researchers contested to identify and associate Sudanese culture. Many claimed that Sudan is an Arabo-Islamic country, thus the culture is associated with the Arabs. Southern writers refuted these claims, calling for the Africanization of Sudan which is rooted in the Dark Continent. If culture is a man-made set of traditions and norms passed on between generations, then being African has more to do with the geographical ties than cultural ones. The same applies to bring Arab; whereas it is a sentimental affiliation to some groups. ${ }^{9}$

Simply, because the process started as a product of intensive interaction with Arab traders in the North, who propagated the culture, traditions and social relations. Arabs came from a faraway land which was rich in innovations and products that reflected their advancement in contrast to Sudanese ways. Although this rings true, it can also be explained by many factors, namely overt Sudanese chauvinism. Thus the history of Arabization and Islamization of Sudan remains a complex process of local interactions and external links especially with Egypt. Thus, the South was not spared from these intimate interactions of Arabs-Islamic cultures with other Africans. ${ }^{10}$

The identity discussion on whether Sudan was Arab or African came to an end after the secession of the South. The Southern identity resistance began in Sudan before the Egyptian-British colonialism, when the South was a hotbed of slave trade. The resistance continued on during the colonial period, regardless of Gordon's futile efforts to ban the trade. The first real communication between the Southern and

\footnotetext{
${ }^{6}$ Geddest, Grosset. Webster's Integrated Dictionary and Thesaurus. USA Geddes \& Grosset; 2006. 1104 p.

${ }^{7}$ Aminu, Jubril. Towards a strategy for education and Development in Africa. In: Nura Alkali, editor. Islam in Africa. Nigeria: Spectrum Books Limited; 1993. $88 \mathrm{p}$.

${ }^{8}$ Deng Aling. Exploring the Identity of Sudanese culture. Is it Arabic or African. 2016.

${ }^{9}$ Aling

${ }^{10}$ Aling
}

Northern cultures was during the Mahdi time after he fought off and evicted the Turks. Southerners called the Mahdi "Madi" and likened him to "Deng Dit" a mythical good omen in Southern folklore. Although the Mahdi failed to halt the slave-trade, he remained a salvation figure in folk Dinka songs. Communication between the North and South has continued until today. However, discussions and research on whether the Southern culture is Arab, African or a mix of the two has also dwindled. Perhaps this is due to many writers proposing that the South or more accurately Southern culture- has now become purely African after separation from the North. ${ }^{11}$

However, the fact is that South Sudanese culture is deeply embedded with African culture, in traditions, music, drums and dancing. Although some of these aspects are threatened with extinction. While on the other hand, Arab culture is also ingrained in the South, starting with literature, short stories, fiction and poetry. Many young literary professionals are fluent in Arabic even though the Southern literature isn't as rich as the Arabic one in the North. ${ }^{12}$

Although certain Western Scholars attempted to deny that Africa had its own religion, not to say the knowledge of God, but the fact is that, Africans, like any other people, are capable of receiving and responding to the revelation of God, which appears to be a universal phenomenon ${ }^{13}$. According to Islam, religion was taught to every race, and in all parts of the world. We read from Qur'an, the Holy Book of Islam: "And we did raise among every people a messenger preaching worship Allah and shun the Evil one ${ }^{14}$ ". Thus, God did not neglect the people of Africa. But, at the time of advent of Islam, African religion, more or less was forgotten, or was in the process of atrophy and being emptied of their spiritual content and their former deed metaphysic. The jumble of empty forms they had left behind could not compete with Islam on the moral or rational level. ${ }^{15}$ This is because, Islam is both a highly developed religious system as well as an established and distinctive culture embracing every aspects of human activity ranging from theology to philosophy, from literature to the visual arts and even down to man's routine daily conduct. ${ }^{16}$

\section{Islamization and arabization of the north Africa}

The Islamization of Africa has been a long, uneven and, indeed, complex process. Islam first contact with Africa was with Ethiopia rather than Egypt and the rest of North Africa. ${ }^{17}$ It is a well known fact that the prophet Muhammad sent a group of his early followers to Ethiopia when life in Mecca became unbearable as a result of their persecution in the hand of Quraysh Oligarchy. ${ }^{18}$ The arrival of the refuges marked the earliest contact between nascent Islam and Ethiopia, and stand out as a significant milestone and point of departure for the history of Islam in African continent. Then in the year 627, the Prophet sent emissaries to various rulers, including the

\footnotetext{
${ }^{11}$ Aling

${ }^{12}$ Aling

${ }^{13}$ Udo Etuk. Religion and cultural identity. Nigeria: Hope Publications; 2002. p. 30-3I.

${ }^{14}$ Quran 16: 36.

${ }^{15}$ Abubakr Ben Ishmael Salahuddin. Islam and African people. The Review of Religions. 1997;92(5/6):5

${ }^{16}$ Malik, Sayed HA. Shariah: A legal system and a way of life. In: AbdulRahmon MO, editor. Perspectives in Islamic law and Jurisprudence. Nigeria: National Association of Muslim Law Students (NAMLAS); 2001. p. 26-27.

${ }^{17}$ Kokole, supra not no. 1:233.

${ }^{18}$ Ali, Maulana Muhammad (1972) Muhammad the Prophet. Ahmadiyya Anjuman Ishaat Islam. Pakistan; 1972. 72 p.
} 
Negus of Ethiopia inviting them to accept Islam. It is stated that his letter was received with dignity and according to some commentators, the Negus is said to have acknowledged and accepted the prophethood of Muhammad and also that the Prophet prayed for him at the time of the death of the Negus's death. ${ }^{19}$ Also seems to have been sent to the Ethiopia monarch by prophet Muhammad and some stayed back, never to return to Arabia. They seem to have been well received there and even protected by the Emperor, despite strong protest by their adversaries. ${ }^{20}$

Tradition has it that the prophet called for a special prayer, probably the first and only of its kind in Islam, when the Ethiopia emperor dies. Abu Hurairah reported, the messenger of Allah, gave the news of the death of Negus on the day on which he died. He went forth to the place of prayer, made the people stand in ranks, and uttered four takbir. ${ }^{21}$ This special relationship with Ethiopia is perhaps a partial explanation of why Muslims did not attempt either a conquest or a vigorous Islamization of the country. ${ }^{22}$

However, it was the Muslim conquest of Egypt in 640 A. D, which initiated a more fundamental process of Islamization in Africa and by the end of that century. Islam had reached the Atlantic. Then it took centuries to consolidate its gains and only gradually turned to the south. The process of Islamization in Africa countries to the present day, and is of several phases, varying in depth and style of the spread of the Islamic heritage. ${ }^{23}$

Besides Ethiopia came an Arab Muslim thrust across North Africa from Egypt to Morocco from the East Westwards, in a way fundamentally reminiscent of the way North America was colonized by the Europeans from the east westwards. However, unlike white Americans, which tended to emphasized its innovative essence, its newness, and to underplay it is European to over-emphasized, sometimes even exaggerate, its link with the Arabian Peninsula. It is of course, true that all Muslims look to Mecca as the spiritual centre of Muslims. ${ }^{24}$ But, North Africans have usually over stated their Arab connection in other words; North Africans looked to Arabian Peninsula for its myth of origin and the rest of the world as a potential area of Islamic recruitment. Thus, as in America, the Muslims in presence in Africa were established by a lengthy period of pacification and consolidation of Muslim control, from the 650 to 10503 A.D.

Unlike the rest of the continent, two processes were underway in North Africa. Islamization was one Arabization was another. By Islamization we refer to the process by which the people of North Africa were converted to Islam and became Muslims. On the other hand, by Arabization we refer to the acculturation process by which the North Africans became among the other things, speaking of the Arabic language as well as being absorbed into other aspects of Arab culture with time, Islamized North Africans came to see themselves as Arabs. ${ }^{25}$ Therefore, one of the primary effects of the spread of Islam into North Africa was the acceptance of the Arabic language.

${ }^{19}$ Trimingham JS. A History of Islam. UK: Oxford University Press; 1974. p. 45-46.

${ }^{20} \mathrm{Ahmad}$, Husseun. Trends and Issues in the history of Islam in Ethiopia. In: Nura Alkali, editor. Islam in Africa. Nigeria: spectrum Book Limited; 1993. 205 p.

${ }^{21}$ Al-Asqalani, Al-Hafidh Ibn Hajar. Bulugh Al-Maram. Saudi Arabia: Dar-ussalam Publications; 1996. 193 p.

${ }^{22}$ Kokole. 233.

${ }^{23}$ Kokole. 233

${ }^{24}$ Kokole. 233

${ }^{25}$ Kokole. 233
Language is one of the main cultural influences left behind by most invading forces: the Romans brought Latin to its European conquests, providing the roots of modern Romance languages and much of English, and through political control, the Arabs made Arabic the predominant language in North Africa. There is no other part of Africa where political control went hand in hand with the spread of Islam. Islamic expansion into Morocco also paved the way for the invasion of southern Spain that introduced Islam into Europe. ${ }^{26}$

\section{Islam and the African continent}

Islam registered its initial impact on East Africa at approximately the same time it did in North Africa. It did so primarily through trade across the Red sea and the Indian Ocean into the Horn of Africa and the East Africa coast, not through armed conquest, as was the case in North Africa. The legendary dhows from Arabia were the critical means of mobility required and these were helped by the monsoons. Cheik Anta Diop argued in support of this assertion and dispelled the charge that Islam was forced on African people he says:

The primary reason for the success of Islam in black Africa, with one exception, consequently stems from the fact that it was promulgated peacefully, at first by solitary Arab-Berber Travelers to certain Black kings and notables, who then spread it about them to those under their jurisdiction. What is to be emphasized here is the peaceful nature of this conversion, regardless of the legend surrounding it. During the period of our study, from the third to the seventeenth centuries, not one conquest was ever launched by way of the Nile nor was there ever an Arab conquest of Mozambique or any other East African country. The Arabs in these areas, who became great religious leaders, arrived as everywhere else individually and settled in peacefully; they owe their influence and latter acceptance. ${ }^{27}$

Later, Islam spread from the north southwards across the Sahara, largely through peaceful migration and trade from around the middle of the $11^{\text {th }}$ century on wards. Just as the dhows had been sailed across the red sea and the Indian Ocean to the eastern seaboard of the African continent, the caravan now cross the Sahara to black Africa, thus, the carriers of Islam generally went overland into tropical Africa. ${ }^{28}$ This was a period of deeper penetration and consolidation of inner East and West Africa through trade, settlement and proselytization.

Roughly in the late $17^{\text {th }}$ century came the establishment of the various Islamic states of the sub-Sahara region. In this stage, the principles of jihad was mobilized through part of the Sahara area to establish and consolidate a multiplicity of Islamic theocratic states culminating in Sokoto Empire of Northern Nigeria and Mahdist state in the Sudan. ${ }^{29}$ The consolidation of Islamic states in sub-Saharan Africa resulted in the disintegration of some social and ethnic group, and it eliminated organized cuts, thereby leaving Islam as credible force and cement for social cohesion. Thus, peaceful conditions and facilities for communication later enable Muslim traders and teachers to circulate freely and propagate their faith at a period when the religious and social structure of many traditional societies were disintegrate under the pressure of various social and economic factors. ${ }^{30}$

Giving this broad framework of the various phases of Islamization in African the following particular characteristics of African Islam may

\footnotetext{
${ }^{26}$ Eleanor McKenzie. The Islamic Effect on Africa. 2017.

${ }^{27}$ Salahuddin. supra note no. 10.

${ }^{28}$ Kokole. 234.

${ }^{29}$ Kokole. 235

${ }^{30}$ Kokole. 235
} 
be observed that after the initial military phase in North Africa, Islam spread through population movement and trade, and was consolidated by proselyzation before the establishment of the Islamic states of the sub-Sahara region. Difference in styles and methods of the spread of Islam in various parts of Africa include variations in the nature of the migrant Muslims population and their religious attitudes. In East and Horn of Africa there were Somali people, Arab and Arabic- speaking peoples in Egypt, North Africa, and North East Africa; and in the east of the West Africa, there were Berbers. Clearly, each migrant group had its own way of travel, trade and style of interacting with the host peoples and this had an effect on the manner and quality of the respective method of Islamization.

\section{Adaptability culture of islam}

An additional factor that may have contributed to the success of Islam in Africa may be the adaptability culture of Islam to various local circumstances. This is because (urf) which means custom; and usage of a particular society, both in speech and in action is accepted as a source of Islamic legislation insofar as it means the customs and usages of a particular area. ${ }^{31}$ Provided there is no contradiction between this and the two chief sources, the Qur'an and normative practice of the prophet, the sunnah and the practice do not cover only habits of dress or language, but also ways of doing business, of celebrating important occasions, and so on. Over time, certain norms come to function as expected standards for a particular service or profession without necessarily being explicitly stated in legal terms. Similarly, certain kinds of commercial transaction are done because of mutual understanding of terms that are not necessarily written out. ${ }^{32}$ The basis for the acceptance of local customs and practice is Qur'an and Sunnah. Some of the pre-Islamic practices of the Arabs were approved and some annulled by the Qur'an; similarly, the prophet accepted some of the inherited ways of doing things, forbade or altered others. ${ }^{33}$

Adaptability of culture made Islam acceptable to Africans who had religions of their own; for example, drum and dancing became part of Islamic celebration in parts of East Africa, to the charging of Islam purist there. Indeed, the Islam of the East African coast bear strong traces of indigenous African religions in the prominence of beliefs in spirits possession, ancestor worship, witchcraft and sorcery, all of which have been maintained by a local oral tradition of Islam which has coexisted with the more orthodox written tradition ${ }^{34}$. Thus, it is safe to say that truths of Islam seem less foreign to indigenous values and their adaption therefore causes less disruption.

\section{The role of trade in the islamaization of Africa}

In essence, the spread of Islam in Africa can be seen in term of the direction and character of long distance trade along ancient coasts. Camel-owing African people such as the Berbers of North Africa and the Somali and Afar peoples of North-East Africa were very instrumental in spreading Islam along the routes of their longdistance caravan trade. Other Muslim traders including the Hausa and Karimiya of Kanem in the east, and the Dyula in the far west and

${ }^{31}$ Said Ramadan. Islamic Law. Sh Muhammad Ashraf. Pakistan; 1970. 33 p.

${ }^{32}$ Chaleby, Kutaiba S. Forensic Psychiatry In Islamic Jurisprudence. Malaysia: The Other Press; 2004.

${ }^{33}$ Doi, Abdur Rahman I. Shariah: The Islamic Law. UK: Ta Ha Publishers; 1984. $84 \mathrm{p}$.

${ }^{34}$ Amponsah, Kwabena. Topic On West African Tradition Religion. Ghana: Mfantsiman Press Ltd; 1975. 2:82 p.
Muslim craftsmen such as the Kotokoli of Togo and Bauba of Benin were also important agents of Islamization within the communities in which they operated. These traders and craftsmen successes in establishing an extensive network of trade centers in the $14^{\text {th }}$ and $15^{\text {th }}$ centuries which later were to serve as a springboard from which to spread Islam throughout Hausa land, the Senegambia and the Guinea Coast. The easiest trade routes were from Morocco down the Western Coast. And up to the River Senegal, and by the $11^{\text {th }}$ century, Islam began to take root among the black people of the Western Sudan. The ancient empires of Ghana and Mali came to have rulers who were Muslims even if only nominally in the sense that traditional religious tendencies remained. ${ }^{35}$

The role of trade in the fortunes of Islam must of course be tied to the biography of the prophet of Islam himself. Prophet Muhammad had earned his living by his shrewdness and reliability as a dealer in the caravan trade, on his own account and still more on that of others. His good management of the wealth entrusted to him had won him first the esteem and then the affection of a rich Meccan widow, khadija, some years older than him, who had offered herself to him in marriage. Mecca itself was then, and even before Muhammad's time, almost as much a centre of trade as a religious focus for the Arabs from distant parts of the Arabian Peninsula ${ }^{36}$. The forms of business entities as practiced in the historical Islamic era were developments of pre-Islamic practices of the Arabs, generated out of their historic culture and traditions. After the advent of Islam, the prophet did not abolish or prohibit these entities. ${ }^{37}$ Therefore, the Arab Muslims adopted them as part of Islamic business practices.

As already indicated, in Africa, the spread of Islam was closely associated with trade. Islam in Africa flourished where there was some basis of urban culture together with trading relations, which ultimately stemmed from town and cities. In Nigeria today one will observed that in all parts of Nigeria Islam remains by and large, a religion of trading.

\section{Islamic education in Africa}

As in other part of the world, literacy in Africa was connected with religion, so was Quranic education in the life of Africans. Obviously at one time or another Muslims were in a minority in every corner of the continent. In Egypt, where the religion first penetrated the continent, Muslims remained a minority for several centuries, while being politically dominant. Even today eight to ten percent of Egypt population is Christian. Muslims then had to learn right from the beginning, to survive and to preserve their religious integrity within a sea of non-Muslims. Not only did they have to define their identity as against neighbors who belonged to other faiths-Christianity, Judaism and many different African religions- they also had constantly to redefine their own Islamic faith, engaging in self-criticism and seeking to redefine their faith in the light of what they learned from scholars of the wider Islamic world. Over the centuries cities in Africa themselves became centers of scholarship where the great issues of the faith were debated and new teachings evolved. Cairo, which was founded in $969 \mathrm{~A}$. D; soon had its own mosque- university- al

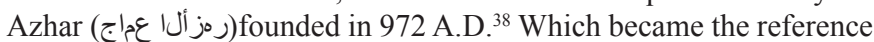
point for orthodoxy among the sunni majority of Muslims. Ez-

\footnotetext{
${ }^{35}$ Kokole. 237.

${ }^{36}$ Ali. supra note no. 8:49-50.

${ }^{37} \mathrm{Ahmad}$, Hashim. Business, corporation and government models in the Islamic economic system. The Review of Religions. 2001.

${ }^{38}$ Karam, Al-Bustani. Al-Munjid fii llugha wal a'ala'am. Lebanon: Dar ElMashreq publishers; $1980.39 \mathrm{p}$.
} 
zeitouna (ننوتيزل) in Tunisia, ${ }^{39} \mathrm{~m}$ Tlemcen (ناسملت) in Algeria ${ }^{40}$ and Qarawiyyin (نيبيورق) in Fez Morocco ${ }^{41}$ also became important centre of Islamic learning in North Africa, while Timbuktu ${ }^{42}$ was a focal point for West Africa scholars from the $14^{\text {th }}$ to the $17^{\text {th }}$ century. In sub-Saharan Africa, however, Islamic knowledge was not the sole prerogative of urban-based scholars. Islamic learning could also flourish in Sahara bases in small towns and scholarly settlements such as walata in southern Mauritania, Kalumfaro in Borno North Ea stern Nigeria, Kutranj in Sudan or Lamu on the Kenyan coast. ${ }^{43}$

Traders were often either accompanied or followed by holy men

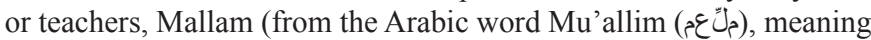
teacher or instructor, who taught the Qur'an as well as other aspects of the Islamic civilizations to the newly converted communities. The activities of these Islamic teachers and scholars led to the grooming of local teachers and scholars from the indigenous populations who were, for obvious reason, particularly effective in their own communities. This Islamic practice of opening local centre for the purpose of training teachers and scholars drawn from the indigenous population into the teaching and proselytization forces was a clear demonstration that Islam spread without the establishment of a foreign elite's clergy. ${ }^{44}$

Islamic education was introduced in Nigeria, as in other area, simultaneously with the introduction of Islam itself. It was conducted and run in almost the same manner as in other Muslim countries. Two types of schools existed, and these were the Quranic schools and ilm schools. The system was not salary-oriented, though some of the graduates were naturally employed to work in the administration. The system did not produced a separate elite, completely detached from their community, rather, it produced self-discipline citizens socially integrated and their ethical values remained the same as those of their community. ${ }^{45}$ Before the advent of colonial Hausa and Fulfulde, languages were being written with Arabic alphabets. This means that the majority of the people of Northern Nigeria were literates because almost everybody had to go to the Quranic schools.

With the advent of the British administration in Nigeria "the old order changed, giving place to a new". A completely new system of education, the aims and objectives of which were entirely different was imposed. The main concept of the new system initially was to produce clerks and supporting staff who would help the new rulers in their administrative duties. They had to be trained to be loyal to the colonial administration. ${ }^{46}$

Immediately the British entered in to the Northern part of Nigeria they realize the extent of the spread of Islamic education there. Arabic was then the official language used in royal courts, offices and the legal courts. They also find out that the majority of the people were literate because almost everybody had to go to school. ${ }^{47}$ Two drastic changes were immediately introduced:

${ }^{39}$ Al-Bustani. 341.

${ }^{40} \mathrm{Al}$-Bustani. 192

${ }^{41}$ Al-Bustani. 550

${ }^{42}$ Al-Bustani. 192

${ }^{43}$ Hunwick John. Islamic Revival in Africa: Historical and contemporary Perspectives. In: Amidu Sanni, editor. An Unfamiliar guest in a familiar household. Nigeria: Debo Prints; 2003. p. 1-2.

${ }^{44}$ Kokole, pp. 238-239.

${ }^{45}$ Galadanci SAS. "Islamic Education in Africa: Past influence and contemporary challenges". In: Nura Alkali, editor. Islam in Africa. Nigeria: Spectrum Books Limited; 1993. 101 p.

${ }^{46}$ Galadanci. 101.

${ }^{47}$ Galadanci. 102.
1. Arabic desisted to be the official language. English replaced it as the official language of the administration.

2. New alphabet - the Roman alphabet was similarly introduced to replace the Arabic one being widely used by the Muslims.

The significance of this new education policy should be seen in its proper perspectives. Immediately these policies were implemented the entire Muslim community in Nigeria was declared illiterate! Now, everybody had to start from "square one" because none would be recognize as educated unless he or she acquired the new knowledge. With the introduction of the new system of education, Quranic education had been forced out of the orbit for several decades' British administration continued to discourage the old system and encourage the new one. ${ }^{48}$ Despite all these, Muslims in Nigeria remained intrinsically attached to their system of education pursuing it without any assistance from the British administrators. Despite the efforts being made to discourage Quranic school, many children and adults continued to attend Quranic and ilm School respectively but the system remained as it has been without any noticeable change. ${ }^{49}$ And no efforts were made by the colonial government to do anything that would promote Islamic education.

It should be added here that the British administration had now succeeded in labeling the system of education they brought as Western education, while the other one was identified as religious education. The former denote all modern branches of knowledge, while the latter was restrictive and the other retrogressive the Western type was associated with all the science and technological achievements of the modern times while the other was harnessed together with retardation, backwardness and under development. ${ }^{50}$ What the Muslims would have done is to start courses in medicine pharmacy, etc; in order to be able to compete favourably with other Western oriented school for student's preference. But unfortunately they did not do that, or any other thing to improve even the old system of education of their own.

Muslims teachers and scholars performed other functions in nonMuslim communities in West Africa. Their knowledge of classical Arabic and their extensive contacts in the broader world enabled them to act as negotiators and mediators both internally and externally with and between the various kingdoms and chiefdoms in the region. This was their diplomatic function. In addition, they also performed accounting and other administrative tasks. Their expertise and skill often brought them in to closer contact with the inner and higher ruling circles. In addition, their nearness to the corridors of power enhanced their prestige among the wider society thereby enabling them to emerge as effective proselytizers. ${ }^{51}$

It was through these means, severally or by a combination of them, that Islam was able, over a period of several centuries, to spread through the centralized or closely centralized states of West Africa as well as through the decentralized communities of East Africa. Today, Islam is probably the fastest growing religion on the African continent. And the proselytization is undertaken by the African Muslims themselves.

\section{Islamic culture and shariah in Nigeria}

Trans-Sahara trade with North Africans and Arabs began to
${ }^{48}$ Galadanci. 102
${ }^{49}$ Galadanci. 103.
${ }^{50}$ Galadanci. 103 .
${ }^{51}$ Kokole. 239. 
transform these northern societies greatly. Increased contact with the Islamic world led to the conversion of the Kanem-Borno Empire to Islam in the eleventh century. This led to a ripple effect of conversions throughout the north. Islam brought with it changes in law, education, and politics. The trans-Sahara trade also brought with it revolutions in wealth and class structure. We can say therefore that, the history of Shari'ah as a system of administration of justice predated the popular amalgamation of the protectorates of Northern and Southern Nigeria. The protectorate of Northern Nigeria is virtually made up of Sokoto caliphate, which was established in 1804. As for Borno Empire, though the rulers of Borno embraced Islam as earlier stated, the structure of the monarchy remained traditional, with the queen mother and other female officials exercising considerable power. The selection of the monarch, the coronation rites, and other bases of royal authority were dictated by pre-Islamic beliefs. The princes and other members of the royal family were granted fiefs and posted away from the capital to govern frontier zones, while people of slave origin were preferred for the royal guard and palace officials..$^{52}$ However, Islamic culture had been deeply entrenched especially since the time of Idris Aloma (1571-1603). In all the places under the influence of Sokoto and Borno Empires, Islamic law (Shari'ah) flourished well. ${ }^{53}$ Through the agency of itinerant Muslim scholars and merchants, Islam had reached the black Africa as far as the 11th century A.D. Commoners and rulers had embraced it and were practicing it with varying degrees of understanding of its precepts and attachment to its ideals. ${ }^{54}$ Rulers were known to have attempted fashioning their administration as closely as possible on the prophetic model. Some of these rulers are known to have requested outstanding Muslim scholars of their times to write political treatises deriving guidance from the Sunnah. ${ }^{55}$

By the late eighteenth century, many Muslim scholars and teachers had become disenchanted with the insecurity that characterized the Hausa states and Borno. Some clerics (mallams) continued to reside at the courts of the Hausa states and Borno, but others, who joined the Qadiriyah brotherhood, began to think about a revolution that would overthrow existing authorities. Prominent among these radical mallams was Usman dan Fodio, who with his brother and son, attracted a following among the clerical class. ${ }^{56}$

As the centuries went on, strict Islamists, many of whom were poor Fulani, began to tire of increasing corruption, excessive taxation, and unfair treatment of the poor. In addition, the practice of Islam had come to be mixed with some identifiable traditional idol worshipping. General ignorance of the religion pervaded the society. At the same time, a dispersed group of Muslims was pursuing vigorous scholarship in the best tradition of Islam. On the other hand, the traditional leadership in many part of pre-jihad Hausa land was becoming despotic. It taxed the citizens heavily. It confiscated property unjustly. It threatened to stand in the way of the pursuance of scholarship. Maters came to a head when king Nafata of Gobir issued a proclamation curbing the activities of Shehu Uthman and his supporters, and prohibiting conversion to Islam and the application of the Islamic teachings on dress. His successor, Yunfa, attacked the

${ }^{52} \mathrm{http}$ //en.wikipedia.org/wiki/kane_borno.

${ }^{53}$ Ambali AMA (2001) Shari'ah and its relevance in the contemporary Nigeria. In: Oloyede Abdul Rahmon M, editor. Perspectives in Islamic law and Jurisprudence. Nigeria: National Association of Muslim Law Students (NAMLAS); 2001. 75 p

${ }^{54}$ Yadud, Auwalu Hamisu. The prospects for Shariah in Nigeria. In: Nura Alkali, editor. Islam in Africa. Nigeria: Spectrum Books Limited; 1993. 40 p. ${ }^{55}$ Yadud. 40

${ }^{56}$ Usman dan Fodio and the Sokoto Caliphate.
Muslims, ordered Shehu Uthman, and his followers to vacate Degel with his family so that he could attack and destroy the rest of the inhabitants. Shehu Uthman of course refused to leave his followers at the mercy of Yunfa and his supporters. He chose to leave with his followers. He migrated to Gudu on $10^{\text {th }}$ Dhul Qadah 1218 A. H/21 February 1804 A.D. ${ }^{57}$ Thus, the community now needed a leader who was to guide it in all matter..$^{58}$ Many of the Fulani led by Usman dan Fodio were unhappy that the rulers of the Hausa states were mingling Islam with aspects of the traditional regional religion. They discussed the matter and finally decided to elect Shehu Uthman as their leader. Shehu Uthman Dan Fodio'(Arabic: يدوف نب نامثع ، (ويدوف ناد نامثع (s) was well educated in classical Islamic science, philosophy and theology and became a revered religious thinker. His teacher, Jibril ibn Umar, argued that it was the duty and within the power of religious movements to establish the ideal society free from oppression and vice. His teacher was a North African Muslim alim who gave his apprentice a broader perspective of the Muslim reformist ideas in other parts of the Muslim world. Dan Fodio used his influence to secure approval to create a religious community in his hometown of Degel that would, Dan Fodio hoped, be a model town. He stayed there for twenty years, writing, teaching, and preaching. ${ }^{59}$

Dan Fodio thus became the leader and commander of the Muslim community who took the oath of allegiance to listen to and obey him while swore to be guided by the Islamic constitution, namely Quran and Sunnah. ${ }^{60}$ With this development, two communities now existed in Hausa land, the community that accepted the Hausa kings and their way of life and that which accepted Islam as their way of life and had accepted the leadership of Shehu Uthman. King Yunfa of Gobir, along with the other Hausa kings, now united in their effort at crushing the threat posed by Shehu Uthman and his supporters. ${ }^{61}$ This led to the Jihad, an armed struggle initiated to defend the Shehu's community from the pillage and aggression, which ended in a triumphant victory for the Shehu Uthman, and consequently facilitated the establishment of a state which derived its legitimacy from the Shari'ah and whose leaders governed in accordance with same. ${ }^{62}$ Thus, Dan Fodio created a theocratic state with a stricter interpretation of Islam, and founded on the principles of the Shari'ah and in which consent of the people provided further legitimacy for governance. Politically, the Shehu, the commander of the faithful, headed the caliphate at the centre with power dispersed and delegated to flag-bearers, the Emirs, in provinces. ${ }^{63}$ This structure was complemented by other offices as those of muhtasib, keeper of public moral ${ }^{64}$ the wazir, who served as the conscience and chief advisers to the province and major centres. Their primary function was to remove injustice, redress wrongs, restrain aggressors and ensure the prevalence of justice generally, and to do all these in accordance with the divinely ordained Shari'ah. The object of the state was to promote and defend the faith and welfare of the community and provide, through its various agencies, amenities

\footnotetext{
${ }^{57}$ Usman dan Fodio and the Sokoto Caliphate. Supra note no 51.
}

${ }^{58}$ Gwandu AA. Aspects of the administration of justice in the Sokoto caliphate and Shaykh Abdullah Ibn Fodio's contribution to it. In: Syed Khalid Rashid, editor. Islamic Law in Nigeria (Application \& Teaching). Nigeria: Islamic Publication Bureau; 1968. 12 p.

${ }^{59}$ Usman dan Fodio and the Sokoto Caliphate. Supra note 51.

${ }^{60}$ Gwandu. 12.

${ }^{61}$ Gwandu. 12

${ }^{62}$ Yadud. p. $40-41$

${ }^{63}$ Yadud. p. $40-41$

${ }^{64}$ Al-Mawardi, Ali bin Muhammad Habib. Al Ahkam al-Sultaniyyah wa liwilay'at al-Diniyyah. Egypt: Dar al-Fikr Lil-tiba'ah wa-Nashr wa-Taowzi'I; 1983. 207 p. 
that would enhance the livelihood of the faithful on earth and facilitate their obedience to Allah, their creator and sustainer. ${ }^{65}$

By the middle of the nineteenth century, there were thirty emirates and the capital district of Sokoto, which itself was a large and populous territory although not technically an emirate. All the important Hausa emirates, including Kano, the wealthiest and most populous, were directly under Sokoto. Adamawa, which was established by Fulani forced to evacuate Borno, was geographically the biggest, stretching far to the south and east of its capital at Yola into modern Cameroon. Ilorin, which became part of the caliphate in the 1830s, was initially the headquarters of the Oyo cavalry that had provided the backbone of the king's power. An attempted coup d'état by the general of the cavalry in 1817 backfired when the cavalry itself revolted and pledged its allegiance to the Sokoto Caliphate. The cavalry was largely composed of Muslim slaves from farther north, and they saw in the jihad a justification for rebellion. In the $1820 \mathrm{~s}$, Oyo had been torn asunder, and the defeated king and the warlords of the Oyo Mesi retreated south to form new cities, including Ibadan, where they carried on their resistance to the caliphate and fought among themselves as well. ${ }^{66}$

Crystal clear, Usman dan Fodio's jihad created the largest empire in Africa since the fall of Songhai in 1591. By the middle of the nineteenth century, when the Sokoto Caliphate was at its greatest extent, it stretched 1,500 kilometers from Dori in modern Burkina Faso to southern Adamawa in Cameroon and included Nupe lands, Ilorin in northern Yorubaland, and much of the Benue River valley. In addition, Usman dan Fodio's jihad provided the inspiration for a series of related holy wars in other parts of the savanna and Sahel far beyond Nigeria's borders that led to the foundation of Islamic states in Senegal, Mali, Ivory Coast, Chad, Central African Republic, and Sudan. ${ }^{67}$ An analogy was therefore drawn between Usman dan Fodio's jihad and the French Revolution in terms of its widespread impact. Just as the French Revolution affected the course of European history in the nineteenth century, the Sokoto jihad affected the course of history throughout the savanna from Senegal to the Red Sea ${ }^{68}$

The Sokoto Jihad leaders were paragons of the proper Islamic behavior of piety, commitment and learning. They conducted the affairs of the state purely and strictly on the moral basis of Islamic culture and fundamental principle of Islamic state. They saw every aspect of their conduct of public affairs as part of worship. Their asceticism and self-denial was such that most of them refused to accept stipends from the public treasury (to which they were legally entitled) and maintain themselves on earnings from their labours. ${ }^{69}$ They believe that, a just political administration is that which stands to reclaim other people right for them, from the oppressors, which prevents injustices, restraints evildoers from the nefarious deeds and bring them in line with the law such political administration is the ultimate desire of the Shari' ${ }^{70}{ }^{70}$.

Muhammad Bello (1781-1834), was reported to have advised his officials to shun selfishness and uphold three things for his subjects:

\footnotetext{
${ }^{65}$ Al-Mawardi. p. $20-22$.

${ }^{66}$ Usman dan Fodio and the Sokoto Caliphate. Supra note 51.

${ }^{67}$ Usman dan Fodio and the Sokoto Caliphate. Supra note 51.

${ }^{68}$ Usman dan Fodio and the Sokoto Caliphate. Supra note 51.

${ }^{69}$ Kumo, Suleiman. Shari'ah under colonialism. In: Nura Alkali, editor. Islam in Africa. Nigeria: Spectrum Books Limited; 1993. 2 p.

${ }^{70} \mathrm{Ibn}$ Farhun, Burhnddin Ibrahim. Tabsiratul Hukam. Darul Marifah. Lebanon; 1965. 2:132 p
}

a) To balance what he liked and what he dislikes, that is to abandon what he liked if it was in Muslims interest;

b) To uphold prudence, that is to give preference to peace over personal interests;

c) Not to charge them with what they were incapable of doing in either word or action. ${ }^{71}$

He further advises that, a leader had two kinds of retinue- those who urged him to do good and others who urged him to do badly. But sensible leader did not cling to his tribesmen nor succumb to their temptation or that of close relations, offspring, friends and servants for fear of interference with his official duties and possible in justice but rather he associated himself with sincere companions. ${ }^{72}$

The administration of justice is always regarded as one of the most important function of any Islamic government. It is an incumbent duty upon the caliph, the leader of the Muslim community, to establish and maintain justice among the members of the community. The caliph discharges this responsibility, partially himself but mainly through a number of officers, he appoints to assist him in the governance of the caliphate. One of the most important of these officers is the qadi or judge whose main though not necessarily total, function is to administer justice. $^{73}$

Given the importance to the administration of justice in Islam, Abdullahi Ibn Fodio showed particular interest in the subject throughout his life. He treated the issue at length in a number of his works. The importance he attached to this subject can be gauged from his statement that for a suitable qualified person the administration of justice is one of the greatest acts of worship, a function for which prophets have been sent. The settling of disputes, the suppression of the injustices of the wicked, and the protection of the weak against the powerful ones these functions of the judges are essential to the preservation of the community. The law acts as a deterrent against criminals. By putting in prisons, the members of the community are protected from their crimes and from their infectious and contagious moral diseases ${ }^{74}$ Thus, Islam sets goals, formulates theories, provides tools, makes rules, and legitimates power and authority for the people of Northern Nigeria during the reign of Sokoto caliphate.

Dan Fodio addressed in his books what he saw as the flaws and demerits of the African non-Muslim or nominally Muslim rulers. Some of the accusations made by him were corruption at various levels of the administration along with injustice regarding ordinary people's rights. Usman also criticized the heavy taxation and obstruction to the business and trade of the Hausa states from the legal system. But it is a pity that, this golden rule and culture did not last long.

Unfortunately, by the middle of the century, when the founder of the caliphate has passed away, their successors had become altogether something different. Their conduct and general comportment had become identical in practically every respect with those of the preJihad Hausa rulers, and by the time the British conquered the country, there was not one emirate, throughout the Sokoto Caliphate, where the principals, the methods and the procedures of an Islamic government were applied. The rulers of that time had arrogated to themselves

${ }^{71}$ Bello, Omar. Muhammad Bello's Ideal of Criminal and Political Justice. Islamic Law in Nigeria. In: Syed Khalid Rashid, editor. Nigeria: Islamic publication Bureau; 1986. 37 p.

${ }^{72}$ Bello. 37.

${ }^{73}$ Al-Mawardi. p. 62-63.

${ }^{74}$ Gwandu. 16. 
the powers of the life and death over their subjects in total and contemptuous disregard for the Shari'ah, and original principles upon which the jihad leadership was founded were totally discarded. ${ }^{75}$ The British colonial conquerors were, therefore, virtually liberators of the masses in almost the whole of northern Nigeria, hence, in most places; they met only puny and token resistance.

\section{Conclusion}

We have discovered that the Islamic tradition within the African continent, though less widely distributed geographically, is more deeply rooted than the Western traditions in Africa. The greatest concentration of Islam in Africa is within Saharan West Africa and the Horn of Africa, where countries like Senegal, Guinea Conakry, Somalia, Eritrea, Nigeria and Tanzania also have a majority of Muslims. The remaining black African countries, including Cote Divoire, Ghana Uganda and Kenya have Muslim minorities. Though in Southern African countries, Islam has been the least effective, where countries like Angola, Zimbabwe and the Republic of South Africa have almost no indigenous Muslims of their own. Yet Islam remains one of the main political and social forces in many parts of the African continent, South as well as north of the Sahara and probably the fastest growing religion on the African continent. And

\footnotetext{
${ }^{75}$ Kumo, supra note no 69 at 3.
}

the proselytization is undertaken by the African Muslims themselves and through peaceful means.

The spread of Islam in Africa can thus be attributed to its respect for local cultures. Muslims didn't force Africans to convert to Islam and tolerated converts combining elements of indigenous religions with Islam. In addition, the sense of brotherhood between Muslims also fit well with the African sense of community, and their belief in caring for the less fortunate has had an impact on numerous African communities. Therefore, jihad led by Dan Fodio actually, resulted in a federal theocratic state, with extensive autonomy for emirates, recognizing the spiritual authority of the caliph or the sultan of Sokoto. Thus, their Jihad is not terrorism; their jihad is liberation movement for the liberation of the oppressed citizens. Terrorism is under no circumstances permissible in Islam. Thus, Islam and its law and culture should be judged on the basis of its teachings and not necessarily on the basis of conduct of some of its adherents.

\section{Acknowledgements}

None.

\section{Conflict of interest}

The author declares no conflict of interest. 